Jurnal Keperawatan Silampari

Volume 4, Nomor 2, Juni 2021

e-ISSN: 2581-1975

p-ISSN: 2597-7482

DOI: https://doi.org/10.31539/jks.v4i2.1941

\title{
PELATIHAN KEBIDANAN LANJUTAN PADA BIDAN TERHADAP PENURUNAN ANGKA KEMATIAN IBU
}

\author{
Arif Setiawan $^{1}$, Djazuly Chalidyanto ${ }^{2}$ \\ Universitas Airlangga, ${ }^{1,2}$ \\ arif.setiawan-2018@fkm.unair.ac.id ${ }^{1}$
}

\begin{abstract}
ABSTRAK
Penelitian ini bertujuan untuk mengetahui efektivitas pelatihan kebidanan lanjut dalam menurunkan angka kematian ibu. Metode yang digunakan adalah dengan cara pelatihan, diskusi dan demonstrasi. Jenis penelitian ini adalah descriptive menggunakan data sekunder data kelahiran dan angka kematian ibu. Hasil dari pelatihan berkelanjutan yang dilakukan selama tahun 2016 dan 2017 terbukti menurunkan angka kematian ibu di Surabaya. AKI pada 10 kecamatan yang dilakukan pelatihan pada tahun 2015 adalah 113,7 per 100.000 kelahiran, angka ini masih diatas standar MDGs. Setelah dilakukan pelatihan AKI pada 10 kecamatan yang mendapat pelatihan pada tahun 2016 adalah 81.8 per 100.000 kelahiran dan tahun 2017 adalah 66,5 per 100.000 kelahiran. Hasil dari simple t-test menunjukkan signifikasi penurunan angka kematian ibu dengan $\mathrm{p}=0,04(\mathrm{p}<0,05)$. Simpulan, pelatihan berkelanjutan pada bidan menurunkan angka kematian ibu di Surabaya.
\end{abstract}

Kata Kunci : Angka Kematian Ibu Bidan, Pelatihan Kebidanan

\section{ABSTRACT}

This study aims to determine the effectiveness of advanced midwifery training in reducing maternal mortality. The method used is using training, discussion, and demonstration. This type of research is descriptive using secondary data on birth data and maternal mortality. Continuous training carried out during 2016 and 2017 was proven to reduce maternal mortality in Surabaya. The MMR in 10 sub-districts trained in 2015 was 113.7 per 100,000 births; this figure is still above the MDGs standard. After the MMR training was carried out in 10 sub-districts that received training in 2016, it was 81.8 per 100,000 births, and in 2017 it was 66.5 per 100,000 births. The results of the simple T-test showed a significant reduction in maternal mortality with $p=0.04$ ( $p<0.05$ ). In conclusion, continuous training for midwives reduces maternal mortality in Surabaya.

Keywords: Midwifery Maternal Mortality Rate, Midwifery Training 


\section{PENDAHULUAN}

Masalah kesehatan di Indonesia masih merupakan masalah yang memerlukan perhatian khusus dari berbagai pihak. Terdapat beberapa indikator yang dapat digunakan dalam menilai derajat kesehatan masyarakat. Salah satunya yaitu dapat digambarkan melalui angka kematian ibu (AKI). Nilai AKI menentukan status kesehatan, dan keberhasilan pelayanan program kesehatan ibu dan anak (KIA) diwilayah tersebut. AKI menurut World Healthy Organization (WHO) adalah kematian selama kehamilan hingga dalam periode 42 hari setelah berakhirnya kehamilan, akibat semua sebab yang terkait dengan atau diperberat oleh kehamilan atau penanganannya, tetapi bukan disebabkan oleh kecelakaan atau cidera.

AKI di Indonesia masih tinggi, pada tahun 2012 AKI di Indonesia adalah 359 kematian dalam 100.000 kelahiran, sedangkan di tahun 2015 adalah 305 kematian dalam 100.000 kelahiran. Walaupun sudah terjadi penurunan, namun angka ini masih jauh diatas target Millenium Development Goals (MDGs) yang mentargetkan 102 kematian dalam 100.000 kelahiran. AKI salah satu indikator untuk melihat derajat kesehatan perempuan dan menjadi salahsatu komponen indeks pembangunan maupun indeks kualitas hidup (Sumarmi, 2017). Oleh karen itu, pemerintah harus mencari penyebab angka kematian ibu yang masih tinggi. Selain itu faktor non tekhnis seperti pembiayaan dan pengetahuan pasien tentang persalinan mempunyai peranan dalam peningkatan angka kematian ibu

Bidan sebagai tenaga kesehatan pertama dalam pertolongan persalinan mempunyai peran yang sangat besar dalam mengendalikan angka kematian ibu. Peran bidan memberi asuhan kebidanan melalui konsultasi serta rujukan pada masa persalinan dengan penyulit tertentu dengan melibatkan pasien dan keluarga, mencakup : a. Mengkaji adanya penyulit dan kondisi kegawatdaruratan pada ibu dan persalinan yang memerlukan konsultasi dan rujukan. b. Menentukan diagnosis, prognosis, dan prioritas. c. Memberi pertolongan pertama pada kasus yang memerlukan rujukan. d. Merujuk klien untuk keperluan intervensi lebih lanjut pada petugas/ institusi pelayanan kesehatan yang berwenang. e. Membuat pencatatan dan pelaporan serta serta mendokumentasikan selalu kejadian dan intervensi. Peran bidan tersebut seringkali dilupakan oleh bidan atau dilakukan tidak dengan benar. Akibatnya, proses persalinan tidak berjalan dengan baik ditambah lagi persoalan non tekhnis seperti pembiayaan dan faktor pengetahuan pasien yang kurang berakibat fatal terhadap persalinan tersebut. Oleh karena itu pengetahuan dan ketrampilan bidan dalam proses persalinan itu harus selalu dilakukan peningkatan. Peran Dinas Kesehatan dan Rumah sakit sangat diperlukan untuk mendukung upaya peningkatan pengetahuan dan kerampilan bidan dalam proses persalinan. Selain itu upaya dinas kesehatan dalam membantu biaya dan edukasi ke pasien sangat diperlukan juga dalam mendukung penurunan angka kematian ibu.

Menurut Widyawati (2018) pelatihan merupakan faktor yang mempengaruhi kinerja bidan dalam memberikan ante natal care. Bidan yang memberikan antenatal care yang baik akan dapat mendeteksi kelainan pada kehamilan termasuk preeklamsi dan perdarahan pasca persalinan. Perbedaan pelatihan ini dengan pelatihan yang lain ada pada isi dari pelatihan yang mencakup segala aspek yang menghambat proses deteksi dini kelainan pada kehamilan. Pada pelatihan hal yang menghambat seperti masalah tekhnis Ante Natal Care (ANC) sampai masalah administrasi seperti pembiayaan dan identitas pasien.

Salah satu cara untuk meningkatkan pengetahuan dan keterampilan bidan adalah dengan melakukan pelatihan berkala kepada bidan mengenai kehamilan dan kelahiran. Pelatihan asuhan persalinan mampu meningkatkan pengetahuan dan keterampilan bidan akan 
pertolongan persalinan (Khoiriah \& Sari, 2018). Dinas Kesehatan Kota Surabaya bekerja sama dengan RSUD dr Mohamad Soewandhie mengadakan pelatihan untuk meningkatkan pengetahuan dan ketrampilan bidan. Dinas kesehatan menunjuk bidan yang ada di puskesmas dan bidan praktek swasta di kecamatan dengan angka kematian ibu tinggi untuk mengikuti pelatihan tersebut.

Penelitian ini berfokus pada pelatihan kebidanan lanjutan pada bidan terhadap penurunan angka kematian ibu. Selain itu, pelatihan ini masih jarang sekali dilakukan khususnya pada tempat penelitian.

\section{METODE PENELITIAN}

Waktu dan tempat penelitian ini dilakukan pada tahun 2016 dan 2017 di Kota Surabaya. Pelatihan diberikan oleh Tim Dokter RS Soewandhi kepada bidan di 10 kecamatan di Kota Surabaya. Metode yang digunakan adalah dengan cara pelatihan, diskusi dan demonstrasi.

Jenis penelitian ini adalah deskriptif non eksperimental yang bersifat komparatif. Sampel dalam penelitian ini adalah seluruh bidan desa, bidan puskesmas maupun bidan praktik swasta, baik yang belum mengikuti pelatihan yang berada wilayah Surabaya Tengah dan Surabaya Selatan (10 kecamatan). Data dianalisis dengan menggunakan simpel T- test dengan nilai signifikansi $\mathrm{p}<0,05$.

\section{HASIL PENELITIAN}

Tabel. 1

Daftar Jumlah Kelahiran dan Kematian Ibu di 10 Kecamatan pada Tahun 2015, 2016 dan 2017

\begin{tabular}{lcccccc}
\hline \multicolumn{1}{c}{ Kecamatan } & \multicolumn{2}{c}{2015} & \multicolumn{2}{c}{2016} & \multicolumn{2}{c}{2017} \\
& Kelahiran & $\begin{array}{c}\text { Kematian } \\
\text { Ibu }\end{array}$ & Kelahiran & $\begin{array}{c}\text { Kematian } \\
\text { Ibu }\end{array}$ & Kelahiran & $\begin{array}{c}\text { Kematian } \\
\text { Ibu }\end{array}$ \\
\hline Pabean & 1073 & 1 & 1074 & 0 & 1047 & 0 \\
Semampir & 2636 & 1 & 2836 & 2 & 2739 & 2 \\
Krembangan & 1707 & 2 & 1694 & 2 & 1658 & 0 \\
Bulak & 652 & 0 & 676 & 2 & 664 & 1 \\
Kenjeran & 3286 & 8 & 2527 & 4 & 2506 & 2 \\
Genteng & 456 & 0 & 792 & 0 & 749 & 1 \\
Tegalsari & 1188 & 2 & 1366 & 2 & 1312 & 2 \\
Bubutan & 1381 & 2 & 1465 & 0 & 1380 & 0 \\
Simokerto & 1208 & 1 & 1433 & 0 & 1356 & 1 \\
Tambak Sari & 3112 & 2 & 3241 & 4 & 3119 & 2 \\
\hline Total & 16699 & 19 & 17104 & 14 & 16530 & 11 \\
\hline AKI & 113,7 per 100.000 & 81.8 per 100.000 & 66.5 per 100.000 \\
& kelahiran & \multicolumn{7}{c}{ kelahiran } & & kelahiran & \\
\hline
\end{tabular}

Berdasarkan tabel 1 terlihat bahwa setelah program pelatihan kepada bidan ini terlaksana pada 10 kecamatan, terjadi penurunan angka kematian ibu. Penurunan cukup signifikan sehingga memenuhi target MDGs yaitu 102 angka kematian per 100.000 kelahiran. Bahkan ada kecamatan yang jumlah kematian ibunya menurun sampai 50 persen seperti pada kecamatan kenjeran dari 8 kematian ibu pada tahun 2015 turun menjadi 4 kematian ibu pada tahun 2016. Kemudian menurun lagi menjadi 2 kematian ibu pada tahun 2017. 


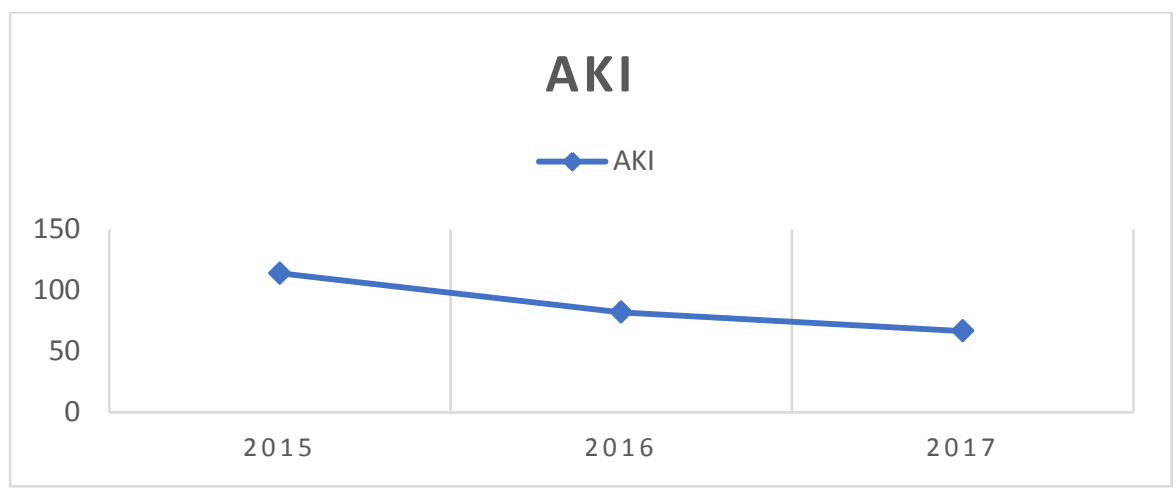

Gambar. 1

Grafik Angka Kematian Ibu di 10 Kecamatan pada Tahun 2015,2016 dan 2017

Berdasarkan gambar 1 menunjukkan grafik penurunan AKI, pada tahun 2015 AKI 113,7 yang berarti belum sesuai dengan standar yang ditetapkan oleh MDGs yaitu 110. Setelah dilakukan pelatihan berkala pada 10 kecamatan, terlihat penurunan signifikan hingga pada tahun 2017 AKI 66,5. Hasil analisis data berdasarka simpel $\mathrm{T}$ - test menunjukkan $\mathrm{p}=0,04$ $(\mathrm{p}<0,05)$. Ini menunjukkan ada penurunan yang signifikan untuk angka kematian ibu di 10 kecamatan tersebut setelah dilakukan pelatihan berkelanjutan pada bidan pada daerah tersebut.

\section{PEMBAHASAN}

Rumah sakit Soewandhi merupakan Rumah Sakit tipe B yang juga merupakan rumah sakit pendidikan. Memiliki visi menjadi rumah sakit pilihan dan unggulan dalam memberi pelayanan dan pendidikan di Kota Surabaya. Serta memiliki misi Memberikan pelayanan kesehatan yang profesional, melaksanakan pendidikan, penelitian di bidang kesehatan yang berkualitas, dan membentuk sumber daya manusia rumah sakit yang kompeten, santun, berintegritas serta membangun kemitraan yang harmoni. Dengan visi dan misi tersebut, RS Soewandhi merasa terpanggil untuk melakukan pelatihan kepada bidan untuk turut serta menurunkan angka kematian ibu di daerah Surabaya.

Berdasarkan observasi yang telah dilakukan sebelumnya, ditetapkanlah bahwa pelatihan yang dilakukan mengenai deteksi dini pada preklamsia pada ibu hamil dan Penanganan Perdarahan pasca melahirkan. Kedua topik ini yang dipilih karena merupakan salah satu penyebab tertinggi kematian ibu. Pelatihan diberikan kepada bidan dengan menggunakan simulasi tentang deteksi dini pada preeklamsia dan perdarahan pasca melahirkan. Setelah dilakukan pelatihan bidan bisa berdiskusi dengan dokter kandungan mengenai kedua masalah tersebut. Bidan juga bisa berkonsultasi apabila ada pasiennya yang mengalami kedua masalah tersebut.

Konsultasi bisa menggunakan whatsapp grup dimana anggota dari grup tersebut adalah dokter kandungan RSUD dr. Mohamad Soewandhie dan semua bidan yang ada di wilayah tersebut. Sehingga bidan bisa sama sama belajar terhadap masalah yang timbul saat menangani pasien dengan preeclamsia dan perdarahan pasca melahirkan. Konsultasi juga bisa dilakukan sejak penanganan awal atau Ante Natal Care (ANC) sehingga bisa dideteksi kelainan kandungan sejak dini. Selain tentang penanganan pasien, grup tersebut juga bisa membantu 
apabila ada problem finansial pada pasien karena pembiayaan untuk pasien yang tidak mampu bisa menggunakan Jaminan Persalinan (Jampersal) yang dibiayai oleh pemerintah. Ini membuat tindakan bisa cepat dilakukan tanpa memikirkan masalah administrasi.

Setelah dilakukan pelatihan selama 2 tahun terjadi penurunan kematian ibu. Penurunan ini disebabkan oleh karena bidan sudah mengetahui tindakan yang harus dilakukan bila terjadi kasus preklamsia pada kehamilan dan juga penanganan kasus perdarahan pasca melahirkan. Hal ini sejalan dengan penelitian sebelumnya yang menyatakan pelatihan asuhan persalinan mempunyai hubungan yang signifikan dengan pengetahuan dan ketrampilan pertolongan persalinan oleh bidan. Pelatihan Asuhan Persalinan mampu meningkatkan pengetahuan dan keterampilan bidan akan pertolongan persalinan (Khoiriah \& Sari, 2018).

Meningkatnya pengetahuan bidan, maka akan meningkat keterampilan bidan sehingga meningkatkan angka harapan hidup ibu (Fitriyya, 2018). Pengetahuan bidan yang bernambah setelah pelatihan seperti kemampuan untuk mendeteksi komplikasi dalam persalinan sehingga bidan dapat merencanakan penolong persalinan pada ibu yang hamil. Ini sesuai dengan penelitian Hidayati \& Safitri (2018) yang menyatakan ada hubungan perencanaan persalinan dan pencegahan komplikasi dengan pemilihan penolong persalinan. Perencanaan persalinan yang bisa dilakukan diantaranya adalah perilaku ibu selama menunggu persalinan seperti makanan yang harus dimakan, pantangan makanan dan gerakan gerakan pada ibu hamil yang mempermudah persalinan (Murdiati \& Jati, 2017; Mariana, 2018).

Pada pelatihan ini juga diberikan cara mengisi buku KIA (Kesehatan Ibu dan Anak) yang baik. Pengisian ini sangat penting sebagai dokumen perkembangan kehamilan yang menentukan proses persalinan yang akan dijalani. Ini sesuai dengan penelitian Suparmi et al., (2020) bahwa ada hubungan kepemilikan buku KIA terhadap peningkatan pemanfaatan pelayanan kesehatan maternal di Indonesia. Adanya pencatatan yang baik di buku KIA membuat deteksi dini adanya kelainan di kehamilan sehingga pasien dapat dirujuk sedini mungkin ketika mengalami komplikasi dalam kehamilan ke fasilitas kesehatan yang lebih tinggi (rumah sakit) sehingga pemanfaatan rumah sakit menjadi meningkat.

Pelaksanaan pelatihan ini dilakukan selama tahun 2016 dan 2017 dengan tujuan untuk menurunkan angka kematian ibu. Hal ini dilakukan karena bidan merupakan tenaga medis pertama dalam penanganan kelahiran, sehingga pengetahuan bidan sangat berpengaruh kepada perawatan yang akan didapatkan oleh ibu hamil. Hal ini sejalan dengan penyebab kematian ibu yaitu 4 terlalu dan 3 terlambat. Pelatihan ini bertujuan untuk memutus penyebab terlambat yang yaitu terlambat mengambil keputusan, terlambat sampai ke tempat pelayanan dan terlambat mendapat pertolongan yang adekuat. Diharapkan bidan dapat memberikan pertolongan yang adekuat pada ibu melahirkan sehingga dapat memperpanjang harapan hidup ibu (Kamidah, 2018).

Penurunan angka kematian ini menunjukkan bahwa pelatihan yang dilakukan efektif dalam menurunkan AKI. Hal ini sejalan dengan penelitian sebelumnya yang menyatakan pelatihan akan membuat perencanaan dalam proses penanganan kelahiran termasuk merujuk pasien dan mempersiapkan darah pada pasien perdarahan pasca persalinan akan menjadi lebih cepat (Hidayati, 2019). Pelatihan ini juga membuat bidan dapat melakukan ante natal care (ANC) menjadi lebih baik.

Menurut Widyawati (2018) pelatihan merupakan faktor yang mempengaruhi kinerja bidan dalam memberikan ante natal care. Bidan yang memberikan ante natal care yang baik akan dapat mendeteksi kelainan pada kehamilan termasuk preeklamsi dan perdarahan pasca 
persalinan. Perbedaan pelatihan ini dengan pelatihan yang lain ada pada isi dari pelatihan yang mencakup segala aspek yang menghambat proses deteksi dini kelainan pada kehamilan. Pada pelatihan hal yang menghambat seperti masalah tekhnis Ante Natal Care (ANC) sampai masalah administrasi seperti pembiayaan dan identitas pasien.

Selain itu, adanya diskusi yang berlanjut di grup whatsapp sekaligus konsultasi ke dokter spesialis kandungan membuat pelatihan ini menjadi lebih bermanfaat dalam menurunkan kematian ibu di kota Surabaya. Peran dinas kesehatan dan RSUD dr. Mohamad Soewandhie sangat besar dalam pelatihan ini. Kedua instansi tersebut telah berhasil mengumpulkan semua bidan di 10 kecamatan untuk mengikuti pelatihan.Selain itu kedua instansi tersebut telah berhasil menggandeng dan memasukkan semua bidan dan dokter kandungan di grup whatsapp sehingga mereka dapat berdiskusi dan berkonsultasi ke dokter kandungan yang ada di rumah sakit. Kedua instansi tersebut juga melakukan monitoring dan evaluasi yang dilaksanakan secara berkesinambungan baik melalui audit maternal perinanatal maupun update ilmu yang dilakukan oleh dokter kandungan di puskesmas. Setelah berjalan 2 tahun pelatihan tersebut telah berhasil menurunkan angka kematian ibu di 10 kecamatan di kota surabaya.

\section{SIMPULAN}

Program Pelatihan bidan yang dilaksanakan oleh tim RS Soewandhi kepada Bidan di 10 kecamatan di kota Surabaya efektif dalam menurunkan angka kematian ibu. Hal ini disebabkan oleh pemilihan topik yang sesuai dengan faktor penyebab kematian ibu, pelatihan yang tepat dalam meningkatkan pengetahuan dan keterampilan bidan sehingga bidan dapat memberikan pertolongan kelahiran yang adekuat.

\section{SARAN}

Sesuai dengan hasil dari pelatihan ini maka diharapkan pelatihan ini semakin diperluas cakupannya. Pelatihan tidak hanya dilakukan pada 10 kecamatan. Namun, diharapkan dapat dilakukan pada seluruh kecamatan agar dapat lebih menurunkan angka kematian ibu dan tetap mencapai angka kematian ibu yang sesuai target standar MDGs.

\section{DAFTAR PUSTAKA}

Fitriyya, M. (2018). Efektifitas Pelatihan Midwifery Update terhadap Peningkatan Pengetahuan Bidan pada Pelayanan Kebidanan di Surakarta. Profesi (Profesional Islam) : Media Publikasi Penelitian, 15(2), 117. https://doi.org/10.26576/profesi.270

Hidayati, N. (2019). Analysis of Implementation Planning Program Delivery and Prevention of Complications ( P4K ) in Preparing Candidate Blood Donors Ready for Use By Village Midwives District Pekalongan. Indonesian Journal for Health Sciences, 2(2), 115. https://doi.org/10.24269/ijhs.v2i2.1346

Hidayati, T., \& Safitri, M. U. (2018). Hubungan Pengetahuan tentang P4k (Perencanaan Persalinan dan Pencegahan Komplikasi) dengan Pemilihan Penolong Persalinan. Keperawatan, 11(2), 1-6. https://ejournal.lppmdianhusada.ac.id/index.php/jk/article/view/14

Kamidah, K. (2018). Program Perencanaan Persalinan dan Pencegahan Komplikasi (P4k) sebagai Upaya Menurunkan Angka Kematian Ibu. Gaster | Jurnal Ilmu Kesehatan, 16(1), 24-35. https://doi.org/10.30787/gaster.v16i1.245 
Khoiriah, A., \& Sari, N. (2018). Gambaran Pengetahuan Ibu Bersalin tentang Pelaksanaan Inisiasi Menyusu Dini di BPM Hj. Rusmiati Palembang. Jurnal Ilmiah Kesehatan, 7(1), 32-36. https://doi.org/10.35952/jik.v7i1.117

Murdiati, A., \& Jati, S. P. (2017). Analisis Faktor-Faktor yang Berhubungan dengan Perilaku Ibu Hamil dalam Merencanakan Persalinan untuk Pencegahan Komplikasi di Wilayah Kerja Puskesmas Bandarharjo Kota Semarang. Jurnal Promosi Kesehatan Indonesia, 12(1), 115. https://doi.org/10.14710/jpki.12.1.115-133

Sumarmi, S. (2017). Model Sosio Ekologi Perilaku Kesehatan dan Pendekatan Continuum of Care untuk Menurunkan Angka Kematian Ibu. The Indonesian Journal of Public Health, 12(1), 129. https://doi.org/10.20473/ijph.v12i1.2017.129-141

Suparmi, S., Maisya, I. B., Rizkianti, A., Saptarini, I., \& Baskoro, A. (2020). Hubungan Kepemilikan Buku Kia terhadap Peningkatan Pemanfaatan Pelayanan Kesehatan Maternal di Indonesia. Jurnal Kesehatan Reproduksi, 11(1), 79-88. https://doi.org/10.22435/kespro.v11i1.3317

Widyawati, W. (2018). Kinerja Bidan dalam Memberikan Pelayanan Antenatal Care dan Faktor yang Mempengaruhi. Jurnal Ilmu Kesehatan Masyarakat, 7(01), 15-24. https://doi.org/10.33221/jikm.v7i01.48 